\title{
RT-PCR AND DOT BLOT HYBRIDIZATION METHODS FOR A UNIVERSAL DETECTION OF TOSPOVIRUSES
}

\author{
MARCELO EIRAS ${ }^{1}$, RENATO O. RESENDE ${ }^{2}$, ALEXANDRE A. MISSIAGGIA ${ }^{2}$ \& ANTÔNIO C. DE ÁVILA ${ }^{3}$ \\ ${ }^{1}$ Centro de Sanidade Vegetal, Instituto Biológico, CEP 04014-002, São Paulo, SP, e-mail: eiras@ biologico.br; \\ 2Departamento de Biologia Celular, Universidade de Brasília, CEP 70910-970, Brasília, DF; ${ }^{3}$ Centro Nacional de Pesquisas \\ de Hortaliças - EMBRAPA, Cx. Postal 218, CEP 70359-970, Brasília, DF
}

(Accepted for publication on $02 / 03 / 2001$ )

Corresponding author: Marcelo Eiras

EIRAS, M., RESENDE, R.O., MISSIAGGIA, A.A. \& DE ÁVILA, A.C. RT-PCR and Dot Blot hybridization for an universal detection of tospoviruses. Fitopatologia Brasileira 26:170-175. 2001.

\begin{abstract}
Transcriptase reverse - polymerase chain reaction (RTPCR) and dot blot hybridization with digoxigenin-labeled probes were applied for the universal detection of Tospovirus species. The virus species tested were Tomato spotted wilt virus, Tomato chlorotic spot virus, Groundnut ringspot virus, Chrysanthemum stem necrosis virus, Impatiens necrotic spot virus, Zucchini lethal chlorosis virus, Iris yellow spot virus. Primers for PCR amplification were designed to match conserved regions of the tospovirus genome. RT-PCR using distinct primer combinations was unable to simultaneously amplify all tospovirus species and consistently failed to detect

ZLCV and IYSV in total RNA extracts. However, all tospovirus species were detected by RT-PCR when viral RNA was used as template. RNA-specific PCR products were used as probes for dot hybridization. This assay with a $\mathrm{M}$ probe (directed to the G1/G2 gene) detected at low stringency conditions all Tospovirus species, except IYSV. At low stringency conditions, the L non-radioactive probe detected the seven Tospovirus species in a single assay. This method for broad spectrum detection can be potentially employed in quarantine services for indexing in vitro germplasm.

Key words: diagnosis, plant viruses, Bunyaviridae.

\section{RESUMO}

\section{Métodos de RT-PCR e de hibridização Dot Blot para detecção universal de tospovirus}

Visando a um método para a detecção universal de tospovírus, utilizaram-se as técnicas de "Transcriptase reverse - polymerase chain reaction" (RT-PCR) e hibridização com sondas marcadas com digoxigenina. As espécies de tospovirus testadas foram: Tomato spotted wilt virus, Tomato chlorotic spot virus, Groundnut ringspot virus, Chrysanthemum stem necrosis virus, Impatiens necrotic spot virus, Zucchini lethal chlorosis virus, Iris yellow spot virus. Os oligonucleotídeos foram sintetizados para anelar em regiões conservadas do genoma viral, sendo os produtos de PCR utilizados como sondas para hibridização através de "dot blot". Através de RT-PCR, utilizando-se diferentes combinações de oligonucleotídeos,

somente foi possível a amplificação de todas as espécies quando se utilizou RNA de vírus purificado, sendo que, para a detecção a partir de RNA total, a RT-PCR apresentou problemas para a detecção das espécies ZLCV e IYSV. Sob condições de baixa adstringência, os testes de hibridização por "dot blot" com a sonda M (correspondente ao gene G1/ G2) detectaram todas as espécies testadas, exceto IYSV. Com a sonda L, também sob condições de baixa adstringência, pôde-se detectar todas as espécies de tospovirus testadas simultaneamente em um único ensaio. Este método de detecção pode ser utilizado em serviços de quarentena e para indexação de germoplasma in vitro.
\end{abstract}

\section{INTRODUCTION}

The genus Tospovirus, within the Bunyaviridae family (Prins \& Goldbach, 1998) is comprised of several species being Tomato spotted wilt virus (TSWV) the type species. This virus is distributed worldwide and occurs in tropical and sub-tropical regions. At present, more than 800 botanical species have been shown to be susceptible to TSWV (Prins \& Goldbach, 1998). In Brazil, several tospovirus species have already been described TSWV, Tomato chlorotic spot virus
(TCSV), Groundnut ringspot virus (GRSV) (de Ávila et al., 1993, 1993a), Chrysanthemum stem necrosis virus (CSNV), Zucchini lethal chlorosis virus (ZLCV) (Bezerra et al., 1999) and Iris yellow spot virus (IYSV) (Pozzer et al., 1999).

In the past, tospovirus strains were identified using differential hosts (Norris, 1946). The development of techniques such as Enzyme linked immunoabsorbent assay (ELISA) (de Ávila et al., 1990), Polymerase chain reaction PCR (Mumford et al., 1994, 1996) and dot blot hybridization (Cho et al., 1989; Rice et al., 1990) dramatically improved 
RT-PCR and Dot Blot hybridization for an universal detection of...

tospoviruses identification. Among these methods, ELISA has been widely applied employing polyclonal antisera directed to the $\mathrm{N}$ protein encoded by the small RNA (de Ávila et al., 1990). This technique, although reliable and as sensitive as dot blot, is virus-specific and in some cases can present high background readings (Rice et al., 1990). With the increasing number of new tospovirus species (Bezerra et al. 1999), a universal method of detection is therefore urgently needed to avoid the introduction of new tospovirus species in distinct regions or countries. A few examples in the literature have already illustrated this threat by showing the spread of INSV in the Northern Hemisphere (Marchoux et al., 1991) and the accidental introduction of CSNV in The Netherlands (Verhoeven \& Roenhorst, 1998).

In this paper, we describe the employment of RT-PCR and digoxigenin-labeled probes for tospovirus species detection. The aim was to develop an universal method to detect a broad number of tospovirus species in a single assay.

\section{MATERIAL AND METHODS}

\section{Virus isolates}

The tospovirus species TSWV, TCSV, GRSV (de Ávila et al., 1993, 1993a), INSV (de Ávila et al., 1993a), CSNV, ZLCV (Bezerra et al., 1999) and IYSV- ${ }_{\mathrm{BR}}$ (Pozzer et al., 1999) were maintained by mechanical passages in Nicotiana benthamiana Domin plants, using phosphate buffer $0.05 \mathrm{M}, \mathrm{pH} 7.0$, under greenhouse conditions. Ten days after inoculation, infected leaves were harvested and stored at -80 ${ }^{\circ} \mathrm{C}$ for analysis.

\section{RNA Extraction and primer synthesis}

Two methods were used for total RNA extraction of the infected $N$. benthamiana: method 1, as described by Chomczynski \& Sacchi (1987) and method 2, as described by de Vries et al. (1982). The purified RNAs from nucleocapsid were extracted according to de Vries et al. (1982).

Four primer pairs were designed to anneal to the conserved regions of the $\mathrm{S}, \mathrm{M}$ and $\mathrm{L}$ segments present in the tospovirus species (Figure 1; Table 1). The first pair, denoted BR60 (viral complementary sense - vc) and BR65 (viral sense - v), was designed to anneal to the conserved region of TSWV S RNA. The BR60 primer (5' CCCGGATCCTGCAGAG CAATTGTGTCA 3', BamHI and PstI sites are underlined) is complementary to the 3' end of the non-translated region of the S RNA (position 1 to 15 nucleotide - nt.) and BR65 primer (5' ATCAAGCCTTCTGAAAGTCAT 3') matches with the sequence corresponding to the $200 \mathrm{nt}$ after the starting codon (AUG) in the open reading frame (ORF) of the nucleocapsid gene $(\mathrm{N})$ (position 433 to $453 \mathrm{nt}$ ).

The second pair of primers, denominated NS1 (vc) and CLA1 (v), was designed to anneal to the conserved region of M RNA. The NS1 primer (5' CCCTGCAGGATCCAGAG CAATCAGTGCA 3', Pst I and BamHI sites are underlined) is complementary to the 5' terminal of the M RNA (position
1 to $15 \mathrm{nt}$.), and the primer CLA1 (5' GCAGGCTTCAATGA ATGC 3') matches with M RNA (position 848 to $865 \mathrm{nt}$ ) in the $\mathrm{NS}_{\mathrm{M}} \mathrm{ORF}$. In the M RNA, two primers denoted BR035 (vc) and PDH006 (v) were synthesized in the conserved regions of the glycoprotein genes $(\mathrm{G} 1$ and $\mathrm{G} 2)$. The primer BR035 (5' GAATATATGACACCATTG 3') is complementary to the terminal region of the M RNA (position 4307 to 4324 nt.), and PDH006 (5' CCCAGAGCAATCAGTGCA 3') matches to the M RNA (position 4801 to $4821 \mathrm{nt}$.).

The L RNA primer, denoted PDH001 (vc) (5' CCC GGATCCTCGAGAGCAATCAGGTAACA 3', BamHI and XhoI sites are underlined), matches with the $3^{\prime}$ terminal (position 1 to $17 \mathrm{nt}$ ), and L1 (v) (5' AATATAACTATAGAA ACGAAA 3') is identical to L RNA (position 711 to $731 \mathrm{nt}$ ). The corresponding locations of the primers were numbered from the RNA segments of TSWV.

\section{Reverse Transcriptase - Polymerase Chain Reaction (RT- PCR).}

The complementary DNA (cDNA) strands for the $\mathrm{S}$, $\mathrm{M}$ and L RNA segments were synthesized by mixing $1 \mu \mathrm{g}$ of total or purified viral RNA, $10 \mathrm{ng} / \mu \mathrm{l}$ of the segment-specific primer pair and $6 \mu 1$ of sterile water followed by heating the mixture at $85{ }^{\circ} \mathrm{C}$ for $2 \mathrm{~min}$ and cooling for $1.5 \mathrm{~min}$. To this mixture, $4 \mu \mathrm{l}$ of reverse transcriptase buffer (5X) (Pharmacia), 1 unit of reverse transcriptase (AMV-RT) (Pharmacia), 1 unit of RNAse inhibitor (RNAsin) (Pharmacia), $0.3 \mu$ l of dNTPs $(25 \mathrm{mM})(\mathrm{USB})$ and $10 \mu \mathrm{l}$ of sterile water were added and incubated at $37^{\circ} \mathrm{C}$ for $1 \mathrm{~h}$.

PCR was accomplished by adding $4 \mu \mathrm{l}$ of Taq DNA polymerase buffer (CENBIOT/RS), $0.3 \mu$ of dNTPs ( $25 \mathrm{mM}$ ) (USB), 2.5 units of Taq DNA polymerase (CENBIOT/RS), $10 \mathrm{ng} / \mu \mathrm{l}$ of each primer, $33 \mu \mathrm{l}$ of sterile water and $10 \mu \mathrm{l}$ of the cDNA. All PCR reactions were performed in a thermal cycler "Gene Amp PCR System 2400" (Perkin Elmer), by pre-heating at $94{ }^{\circ} \mathrm{C}$ for 5 min followed by 30 cycles of 1.5 min of denaturation at $94^{\circ} \mathrm{C}, 2 \mathrm{~min}$ of annealing at $48^{\circ} \mathrm{C}$ and $1 \mathrm{~min}$ for extension at $72^{\circ} \mathrm{C}$. Finally, the amplified DNA was incubated at $72{ }^{\circ} \mathrm{C}$ for $7 \mathrm{~min}$ to accomplish a final extension. Ten $\mu 1$ of PCR reaction were subjected to electrophoresis in $1 \%$ agarose gel and then stained with ethidium bromide $(0.01 \%)$.

\section{Dot Blot Hybridization}

Total RNA extracts $(1 \mu \mathrm{g})$ from each tospovirus species were blotted onto nylon membranes (Hybond-N+, Amersham) using the slot-blot convertible filtration manifold system (Gibco BRL), during $15 \mathrm{~min}$, and fixed by UV irradiation for $5 \mathrm{~min}$.

Using the DIG DNA labeling and detection kit (Boehringer Mannheim), the probes were labeled with digoxigenin by PCR with specific primers for each gene of TSWV (BR60 and BR65: N gene), NS1 and CLA1 ( $\mathrm{NS}_{\mathrm{M}}$ gene), BR035 and PDH006 (G1/G2 gene) and PDH001 and L1 (L gene) (Figure 1). The N probe of CSNV was prepared using a PCR fragment amplified with the primers BR60 and BR65. 
M. Eiras et al.

TABLE 1 - Primers used in RT-PCR, the nucleotide position in the virus genome and the estimated size of the amplified fragments

\begin{tabular}{|c|c|c|c|c|c|}
\hline RNA & GENE & $\begin{array}{c}\text { PRIMER AND } \\
\text { NUMBER OF } \\
\text { NUCLEOTIDES (nt) }\end{array}$ & $\operatorname{Tm}\left(1 \mathrm{M} \mathrm{Na}{ }^{+}\right)^{*}$ & $\begin{array}{l}\text { NUCLEOTIDE } \\
\text { POSITION }\end{array}$ & $\begin{array}{c}\text { EXPECTED SIZE } \\
\text { (BASE PAIRS) }\end{array}$ \\
\hline \multirow[t]{3}{*}{$\mathrm{S}$} & $\mathrm{N}$ & BR60 (27 nt) & $60{ }^{\circ} \mathrm{C}$ & 1 to $15(\mathrm{vc}) * *$ & 453 \\
\hline & & BR65 (21 nt) & $50^{\circ} \mathrm{C}$ & 433 to $453(\mathrm{v})^{* * * *}$ & \\
\hline & $\mathrm{NS}_{\mathrm{M}}$ & NS1 (28 nt) & $63{ }^{\circ} \mathrm{C}$ & 1 to $15(\mathrm{vc})$ & 865 \\
\hline \multirow{2}{*}{ M } & G1/G2 & BR035 (18 nt) & $45^{\circ} \mathrm{C}$ & 4307 to $4324(\mathrm{vc})$ & 514 \\
\hline & & PDH006 (18 nt) & $60^{\circ} \mathrm{C}$ & 4801 to $4821(\mathrm{v})$ & \\
\hline \multirow[t]{2}{*}{$\mathrm{L}$} & $\mathrm{L}$ & PDH001 (29 nt) & $60^{\circ} \mathrm{C}$ & 1 to $17(\mathrm{vc})$ & 731 \\
\hline & & L1 (21 nt) & $41^{\circ} \mathrm{C}$ & 711 to $731(\mathrm{v})$ & \\
\hline
\end{tabular}

* Value of Tm, at $1 \mathrm{M} \mathrm{Na}^{+}$conditions, calculated for each primer according Gibco BRL;

$* * \mathrm{vc}=$ virus complementary sense;

$* * * \mathrm{v}=$ virus sense

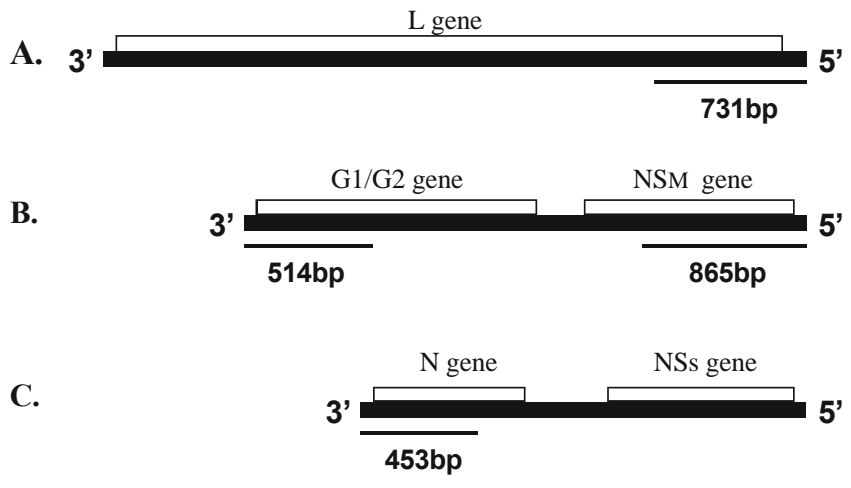

FIG. 1 - Schematic diagram of the genomic L (A), M (B) and $S$ (C) RNAs of the tospovirus showing the location of RT-PCR amplified fragments used as probes for hybridization

The PCR cycles were performed as described previously. After $\mathrm{PCR}$, the amplification products were visualized in a $1 \%$ agarose gel stained with $0.01 \%$ of ethidium bromide.

Each digoxigenin-labeled probe $(5-25 \mathrm{ng} / \mathrm{ml})$ was hybridized for $12 \mathrm{~h}$ at hybridization solution (SSC 5X + SDS $0.02 \%$ + blocking reagent $0.05 \%+$ n-laurylsarcosine $0.1 \%+$ blocking solution $1 / 10 \mathrm{~V})$ under low $\left(45^{\circ} \mathrm{C}\right)$ and high $\left(65^{\circ} \mathrm{C}\right)$ stringency conditions. After washing with SSC $2 \mathrm{X}$ at $25^{\circ} \mathrm{C}$ and twice with SSC $0.1 \mathrm{X}+\operatorname{SDS} 0.1 \%$ at $65^{\circ} \mathrm{C}$, the antiDIG-AP conjugate was added $(75 \mathrm{mU} / \mathrm{ml})$ in blocking solution for $30 \mathrm{~min}$. After treatment with wash buffer (maleic acid $0.1 \mathrm{M}+\mathrm{NaCl} 0.15 \mathrm{M} \mathrm{pH} 7.5+$ Tween $200.3 \%$ ) and detection buffer $(\mathrm{NaCl} 0.1 \mathrm{M}+$ tris $\mathrm{HCl} 0.1 \mathrm{M}+\mathrm{MgCl} 250 \mathrm{mM})$, the membranes were visualized in a solution of nitro blue tetrazolium plus X-phosphate (Boehringer Mannheim).

\section{RESULTS}

\section{PCR detection}

RT-PCR protocol using the four specific primer pairs to the L, M and S RNAs was not able to detect all tospovirus species simultaneously, regardless of whether the total RNA was obtained by either method 1 or 2 . The two total RNA extraction methods had similar efficiency; however, the method 1 was faster to perform.

RT-PCR with primers BR60/BR65, specific to the N gene, amplified fragments of the expected size (453 bp) from samples infected with TSWV, TCSV, GRSV, INSV and CSNV (Figure 2A). With the two tospovirus species ZLCV and IYSV no amplification product was observed. Similar results were obtained with primers NS1/CLA1 that amplified a fragment of $865 \mathrm{bp}$ in the $\mathrm{NS}_{\mathrm{M}}$ gene (M RNA) (Figure 2B).

With the primers BR035/PDH006, specific to the G1/G2 gene, amplification of a 514 bp fragment was observed only for TSWV, TCSV, GRSV, and INSV. With CSNV, ZLCV,7 and IYSV no amplification product was observed (Figure 3A). The primers PDH001/L1 amplified a fragment of $731 \mathrm{bp}$ only for the species TSWV and CSNV. An unexpected fragment of $1000 \mathrm{bp}$ was observed for TCSV. This fragment was not observed in the other tospovirus species. RT-PCR from purified RNA indicated that all tospovirus species could be detected using the BR60/65, BR035/PDH006 and NS1/CLA1 primer pairs (Figure 3). With the PDH001/L1 primers, the results were the same as those obtained for the total RNAs. The same RT-PCR experiments were repeated, at least five times for each virus species.

The digoxigenin-labeled probes were developed and used for dot hybridization. For the $\mathrm{N}$ gene, two $453 \mathrm{bp}$ probes were synthesized. The probe specific for TSWV gave positive reaction with the homologous species and cross hybridized with TCSV and GRSV. The N probe directed to CSNV clearly detected the homologous virus and ZLCV (Figure 4II). A faint reaction with TSWV and GRSV was also observed.

The $\mathrm{NS}_{\mathrm{M}}$ digoxigenin-labeled probe of TSWV (865 bp) detected the homologous virus as well as TCSV and INSV (Figure 4III, IV). Probes directed at the TSWV G1/G2 gene (514 bp) reacted strongly with total RNA extracts of TSWV, 
RT-PCR and Dot Blot hybridization for an universal detection of...

A

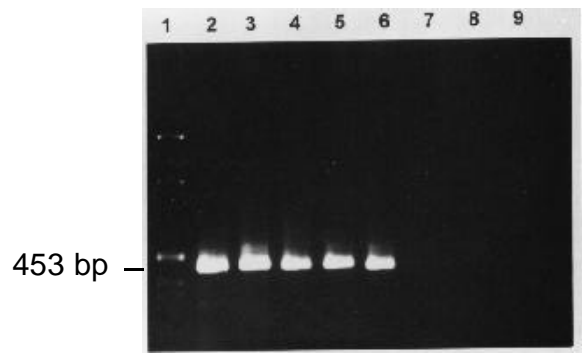

B

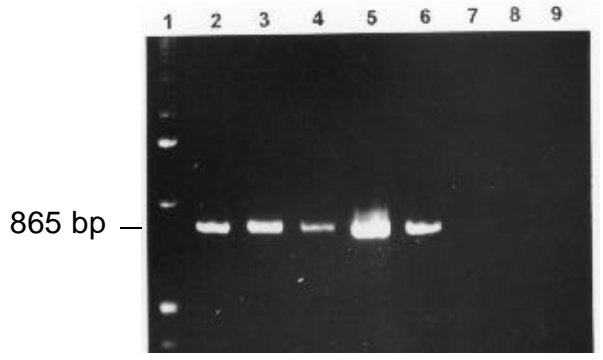

C

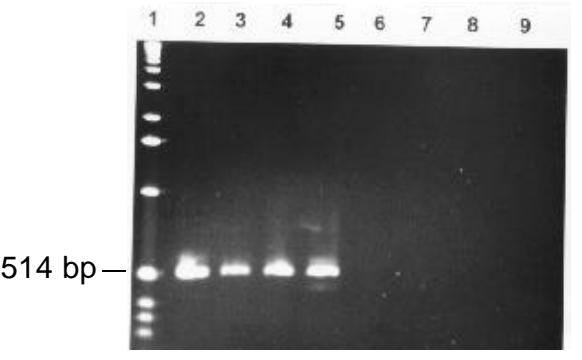

$\mathrm{D}$

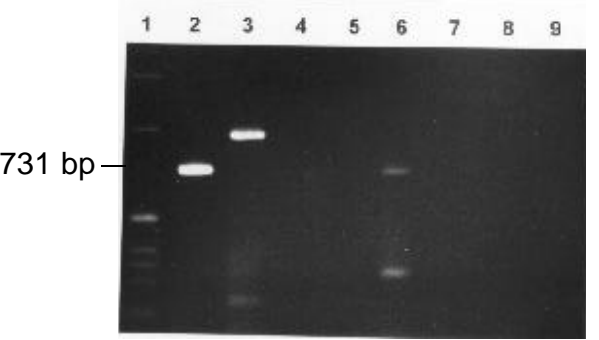

FIG. 2 - Results of RT-PCR for total RNAs samples amplified with primers: BR60/65 (A), NS1/CLA1 (B), BR035/ PDH006(C), and PDH001/L1 (D). Lane 1: DNA Marker (1 kb DNA ladder - Gibco BRL) and lanes 2 to 9 corresponding to TSWV, TCSV, GRSV, INSV, CSNV, ZLCV, IYSV and healthy plant, respectively

TCSV, GRSV, INSV, CSNV, and ZLCV (Figure 6I). The hybridization results using TSWV L specific probe (731 bp) detected all tospovirus species tested (Figure 4VII, VIII). The hybridization with the L RNA probe was repeated at least three times.

\section{DISCUSSION}

The number of distinct tospovirus species has remarkably increased in the last ten years comprising, at present, comprising 12 species (Prins \& Goldbach, 1998). Therefore, a sensitive method to detect a broad number of known tospoviruses and possible new species in a single assay is urgently needed.

Usually most tospoviruses can be mechanically transmitted (Norris, 1946) and they are detected by electron microscopic methods (Kitajima et al., 1992). Although these methods have been widely used, they remain slow, time consuming, inaccurate, and limited with respect to the number of processed samples. In addition, mechanical inoculation is often associated with the generation of defective interfering mutant RNAs (Resende et al., 1991), which can cause a misinterpretation of tospovirus symptoms. Serology using ELISA with antisera directed at the $\mathrm{N}$ protein for tospovirus diagnosis allows a reliable and sensitive detection method (de Ávila et al., 1993a), but is highly species-specific.

This study has demonstrated that RT-PCR and hybridization with RNA-specific PCR fragments probes could achieve universal detection of tospoviruses. Using PCR with primers designed to amplify conserved regions in the $\mathrm{N}$ and $\mathrm{NS}_{\mathrm{M}}$ genes (Figure 1), it was possible, from the total RNA extracts, to simultaneously five distinct tospovirus species (TSWV, TCSV, GRSV, INSV and CSNV) out of the seven tested (ZLCV, IYSV). When RT-PCR with purified viral RNAs were used along with the primers BR60/65, NS1/CLA1 and BR035/PDH006, all tospovirus species were detected. This fact can be explained by the low concentration or instability of these two virus species in total RNA preparations. The RT-PCR from purified RNAs of ZLCV showed amplification products of 500 and $950 \mathrm{bp}$ when the
A

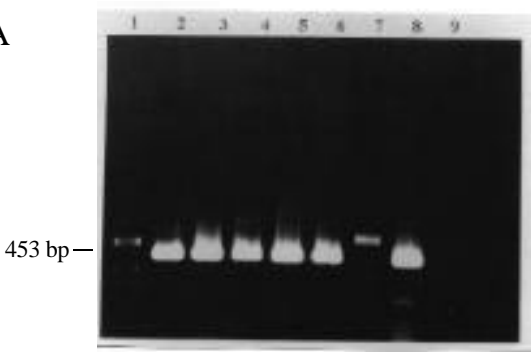

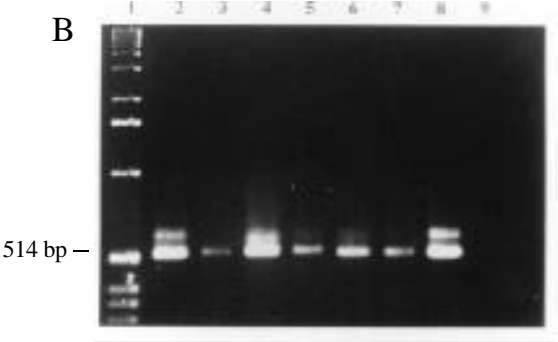

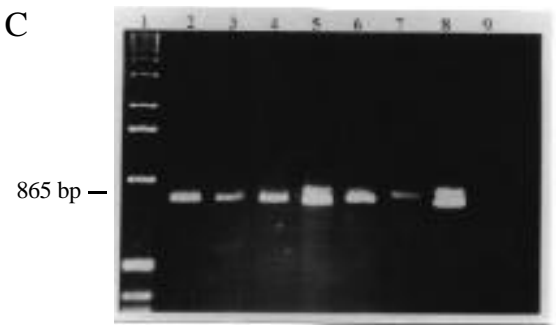

FIG. 3 - Results of RT-PCR for the purified viral RNAs samples amplified with primers: BR60/65 (A); BR035/PDH006 (B) and NS1/CLA1 (C). Lane 1: DNA Marker (Gibco BRL) and lanes 2 to 9 corresponding to TSWV, TCSV, GRSV, INSV, CSNV, ZLCV, IYSV and healthy, respectively. 


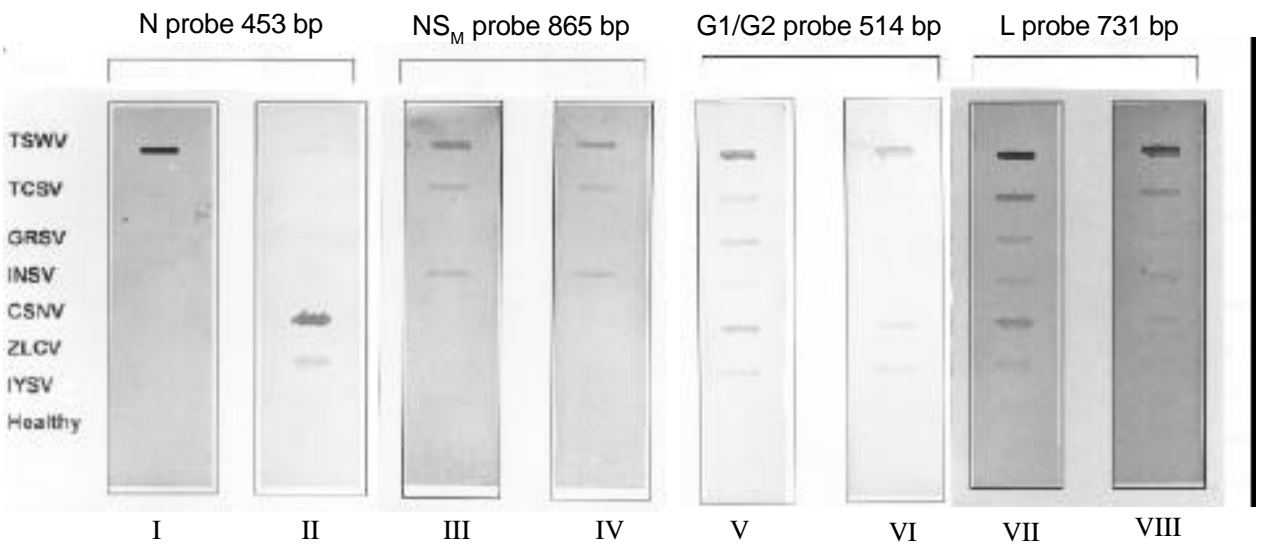

FIG. 4 - Slot blot hybridization with digoxigenin-labeled N specific probes derived from TSWV cDNA (I) and CSNV cDNA (II), $\mathrm{NS}_{\mathrm{M}}$ specific probe derived from TSWV cDNA (III and IV). G1/G2 probe derived from cDNA (V and VI); L specific probe from TSWV cDNA (VII and VIII). Hybridization was performed at $45^{\circ} \mathrm{C}$ (I, II, III, V, and VII) and $65^{\circ} \mathrm{C}$ (IV, VI, and VIII), respectively. Total RNAs from viral infected or non-infected plants were spotted as signaled on the left.

primer pairs BR60/65 and NS1/CLA1 were employed, respectively (Figure 4A,B). These results confirm the sequencing data of the ZLCV N gene, which was shown to be 100 bp longer than any other known tospovirus species (Bezerra et al., 1999).

So far, more than 77 species within 29 genus and 8 families of plant viruses have been detected by PCR (Eiras et al., 1998), including tospoviruses for which PCR has been used showing higher sensitivity than ELISA (Mumford et al., 1994, 1996). Aimed at a universal detection method of plant viruses, primers have been designed to anneal to the conserved regions of several viral genomes, as demonstrated for Cucumber mosaic virus isolates (Hu et al., 1995), several potyviruses (Langeveld et al., 1991), and tospovirus species (Mumford et al., 1996).

Hybridization techniques have been used to detect several plant viruses and have been shown to be more sensitive and more specific than serology (Hahm et al., 1993). Hybridization using cDNA probes (Ronco et al., 1989) and riboprobes (Huguenot et al., 1990) have also been applied to TSWV detection. Dot blot hybridization with digoxigeninlabeled probes has been used for plant viruses other than tospovirus (James et al., 1999). In seeking a broad spectrum detection method, digoxigenin-labeled probes directed at the S, M and L RNAs were developed. The results obtained with the $\mathrm{N}$ gene probe (453 bp fragment) were virus-specific in agreement with ELISA using polyclonal antisera against the $\mathrm{N}$ protein (de Ávila et al., 1990, 1993) and the radioactive hybridization results (Rice et al., 1990) already available.

When the 514 bp fragment corresponding to the G1/ G2 gene was used as a probe, six tospovirus species were detected, excepting only IYSV. This result was expected since IYSV has been shown to be highly distinct from the other tospovirus included in this test (Pozzer et al., 1999). However, with the availability of new glycoprotein gene sequences, new probes capable of hybridizing to the conserved regions of G1/
G2 genes can be synthesized allowing a broader detection spectrum. Therefore, the G1/G2 probes are the most promising candidates for use in universal tospovirus detection.

The L RNA probe (731 bp) showed the broadest detection spectrum. With this probe, the seven tospovirus species could be detected in a single assay using either radioactive (data not shown) or non-radioactive probes (Figure 4 VII). These results confirm the high degree of conservation among the tospoviral polymerase protein, as already discussed by Van Polwijk et al. (1997).

From the results obtained with the G1/G2 and mainly with the $\mathrm{L}$ probe, the hybridization technique designed for conserved tospovirus genes has here been shown to be a suitable method for the universal detection of tospoviruses. In addition, the use of non-radioactive probes is highly recommended since they avoid the hazard of manipulating radioactive materials.

The variability within the Tospovirus genus in combination with the intensive exchange of plant material around the world demands an accelerated development of new diagnostic tools for tospoviruses. The quarantine systems play an important role in indexing plant material to avoid introduction of new tospovirus species within a geographic region, as recently shown for INSV in the Northern Hemisphere (Marchoux et al., 1991), and CSNV in The Netherlands (Verhoeven \& Roenhorst, 1998). The hybridization with the L and $\mathrm{G} 1 / \mathrm{G} 2$ probes, as proposed in this study, is a sensitive and broad-spectrum tospovirus detection method especially suited for use in quarantine services.

\section{LITERATURE CITED}

BEZERRA, I.C., RESENDE, R.O., POZZER, L., NAGATA,T., KORMELINK, R. \& DE ÁVILA, A.C. Increase of tospoviral diversity in Brazil with the identification of two new tospovirus species, one from 
RT-PCR and Dot Blot hybridization for an universal detection of...

Chrysanthemum and one from zucchini. Phytopathology, 89:823-830. 1999

CHO, J.J., MAU, F.R.L., GERMAN, T.L., HARTMANN, R.W., YUDIN, L.S., GONSALVES, D. \& PROVVIDENTI, R. A multidisciplinary aproach to management of TSWV in Hawaii. Plant Disease 73:375383. 1989.

CHOMCZYNSKI, P. \& SACCHI, N. Single-step method of RNA isolation by acid guanidinium thiocyanate-phenolchloroform extraction. Analytical Biochemistry 162: 156-159. 1987.

DE ÁVILA, A.C., HUGUENOT, C., RESENDE, R.O., KITAJIMA, E.W., GOLDBACH, R.W. \& PETERS, D. Serological differentiation of twenty isolates of tomato spotted wilt virus. Journal of General Virology 71:28012807. 1990.

DE ÁVILA, A.C., DE HAAN, P., SMEETE, M.L.L., RESENDE, R.O., KORMELINK, R., KITAJIMA, E.W., GOLDBACH, R.W. \& PETERS, D. Distinct levels of relationship between tospovirus isolates. Archives of Virology 128:211-227. 1993.

DE ÁVILA, A.C., DE HAAN, P., KORMELINK, R., RESENDE, R.O., KITAJIMA, E.W., GOLDBACH, R.W. \& PETERS, D. Classification of tospoviruses based on phylogeny of nucleoprotein gene sequences. Journal of General Virology 74:153-159. 1993a.

DE VRIES, S.C., SPRINGER, J. \& WESSELS, J.G.H. Diversity of abundant mRNA sequences and patterns of protein synthesis in etiolated and greened pea seedlings. Planta 156:129-135. 1982.

EIRAS, M., RESENDE, R.O. \& DE ÁVILA, A.C. Detecção de vírus de plantas através de Reação em Cadeia da Polimerase. Fitopatologia Brasileira 23:5-17. 1998.

HAHM, Y.I., CHOI, K.S., KIM, Y.S., CHOI, J.K., BAE, S.W. \& HWANG, Y.S. Hybridization detection of potato viruses using digoxigenin-labeled RNA probe. RDAJournal of Agricultural Science 35:239-244. 1993.

HUGUENOT, C., VAN DEN DOBBELSTEEN, G., DE HAAN, P., WAGEMAKERS, C.A.M., DROST, G.A., OSTERHAUS, A.D.M.E. \& PETERS, D. Detection of tomato spotted wilt virus using monoclonal antibodies and riboprobes. Archives of Virology 110: 47-62. 1990.

HU, J.S., LI, H.P., BARRY, K., WANG, M. \& JORDAN, R. Comparison of dot blot, ELISA and RT-PCR assays for detection of two cucumber mosaic isolates infecting banana in Hawaii. Plant Disease 79:902-906. 1995.

JAMES, D., JELKMANN, W. \& UPTON, C. Specific detection of Cherry Mottle Leaf Virus using Digoxigeninlabeled cDNA probes and RT-PCR. Plant Disease 83:235-239. 1999.

KITAJIMA, E.W., DE ÁVILA, A.C., RESENDE, R.O., GOLDBACH, R.W. \& PETERS, D. Immuno-electron microscopical detection of tomato spotted wilt virus and its nucleocapsids in crude plant extracts. Journal of
Virological Methods 38:313-322. 1992.

LANGEVELD, S.A., DORE, J.M., MEMELINK, J., DERKS, A.F.L.M., VAN DER VLUGHT, C.I.M., ASJES, C.J. \& BOL, J.F. Identification of potyviruses by polymerase chain reaction with degenerate primers. Journal of General Virology 72:1531-1541. 1991.

MARCHOUX, G., GEBRE-SELASSIE, K. \& VILLEVIEILLE, M. Detection of tomato spotted wilt virus and transmission by Frankliniella occidentalis in France. Plant Pathology 40:347-351. 1991.

MUMFORD, R.A., BARKER, I. \& WOOD, K.R. The detection of tomato spotted wilt virus using the polymerase chain reaction. Journal of Virological Methods 46:303-311. 1994.

MUMFORD, R.A., BARKER, I. \& WOOD, K.R. An improved method for detection of Tospoviruses using the polymerase chain reaction. Journal of Virological Methods 57:109-115. 1996.

NORRIS, D. The strain complex and symptom development of tomato spotted wilt virus. Bull. Aust. Council Sci. Ind. Res. 202. 1946.

POZZER, L., BEZERRA, I.C., KORMELINK, R., PRINS, M., PETERS, D., RESENDE, R.O. \& DE ÁVILA, A.C. Characterization of a distinct tospovirus isolate of iris yellow spot virus associated with a disease in onion fields in Brazil. Plant Disease. 83:345-350. 1999.

PRINS, M. \& GOLDBACH, R. The emerging problem of tospovirus infection and nonconventional methods of control. Trends in Microbiology 6:31-35. 1998.

RESENDE, R.O., DE HAAN, P., DE ÁVILA, A.C., KITAJIMA, E.W., KORMELINK, R., GOLDBACH, R.W. \& PETERS, D. Generation of envelope and defective interfering RNA mutants of tomato spotted wilt virus by mechanical passage. Journal of General Virology 72:2375-2383. 1991.

RICE, D.J., GERMAN, T.C., MAU, R.F.L. \& FUJIMOTO, F.M. Dot blot detection of tomato spotted wilt virus RNA in plant and thrips tissues by cDNA clones. Plant Disease 74:274-276. 1990.

RONCO, A.E., DAL BÓ, E., GHIRINGHELLI, P.D., MEDRANO, C., ROMANOVSKI, V., SARACHU, A.N. \& GRAU, O. Cloned cDNA probes for the detection of tomato spotted wilt virus. Phytopathology 79:1309-1313. 1989.

VAN POELWIJK, F., PRINS, M. \& GOLDBACH, R.W. Completion of the Impatiens necrotic spot virus genome sequence and genetic comparison of the L proteins within the family Bunyaviridae. Journal of General Virology 78:543-546. 1997.

VERHOEVEN, T.J. \& ROENHORST, J.W. Occurrence of tospoviruses in The Netherlands. Abstracts of the $4^{\text {th }}$ International Symposium on Tospoviruses and Thrips in Floral and Vegetable Crops, Wageningen-The Netherlands, pp. 77-80. 1998. 